\title{
Competencies, Roles and Effective Academic Leadership in World Class University
}

\author{
Elham Shahmandi \\ Department of Professional and Continuing Education \\ Faculty of Educational Studies, Universiti Putra Malaysia 43400 Serdang Selangor, Malaysia \\ Tel: +01-7386-7624_E-mail: shahmandyy@yahoo.com \\ Abu Daud Silong (Corresponding author) \\ Department of Professional and Continuing Education \\ Faculty of Educational Studies, Universiti Putra Malaysia 43400 Serdang Selangor, Malaysia \\ Tel: +01-7382-8747Ｅ-mail: Abudaud.silong@gmail.com \\ Ismi Arif Ismail \\ Department of Professional and Continuing Education \\ Faculty of Educational Studies, Universiti Putra Malaysia 43400 Serdang Selangor, Malaysia \\ Tel: +01-7382-8747Ｅ-mail: Ismilina@hotmail.com \\ Bahaman Bin Abu Samah \\ Department of Professional and Continuing Education \\ Faculty of Educational Studies, Universiti Putra Malaysia 43400 Serdang Selangor, Malaysia \\ Tel: +01-9323-0588Ｅ-mail: drbas@ace.upm.edu.my \\ Jamilah Othman \\ Department of Professional and Continuing Education \\ Faculty of Educational Studies, Universiti Putra Malaysia 43400 Serdang Selangor, Malaysia \\ Tel: +01-9328-9493Ｅ-mail: jamilah@ace.upm.edu.my
}

Received: December 20, 2010 Accepted: January 29, $2011 \quad$ doi:10.5430/ijba.v2n1p44

\begin{abstract}
How an academic leader can become more effective? This research question is examined in the context of middle level leadership in research universities that includes the Deans and Head of Departments. It is based on a review of literature that focuses on the investigation of effective academic leadership. In the present situation of globalization, academic excellence is often related to being World Class University. Leadership effectiveness is more related to situational leadership style in research universities and in a global context. Hence situational leadership models such as Hersey and Blanchard and Yetton-Vroom are analyzed. It is suggested that effective academic leaders use the four styles proposed by Hersey and Blanchard that includes "telling, selling, participating and delegating". These styles should be used in relation to ability and willingness of followers to perform the assigned tasks. The review also indicated that to be effective, academic leaders require certain competencies and perform the necessary roles in order to lead. Effective academic leaders need the skills and abilities to lead research universities towards excellence. Roles of academic leaders are examined in relation to Mintzberg leadership roles. The ten roles identified by Mintzberg are categorized into three major roles of interpersonal contact, information processing and decision making. To summarize, effective academic leaders utilized various leadership styles according to certain situations, possessed the required competencies and
\end{abstract}


assumed certain roles when appointed as Deans and Head of Departments in research universities. As such it is important that a systematic leadership development programs should be developed to ensure academic leadership effectiveness.

Keywords: Effective academic leadership, Leadership competencies, Leadership roles, World Class University, Academic Excellent leadership

\section{Introduction}

Today's leaders need to know new knowledge, abilities and skills to effectively cope with the constant organizational changes. The most significant function of an institution of higher learning (IHL) relies on its leadership effectiveness in creating a pleasant teaching environment for faculty and in providing students with quality of education they deserve (Afnan Al-Shuaiby, 2009). Blair (2000) stated that institutions of higher learning are increasingly expecting a Dean to attain external funding to be considered as an effective leader whilst in a recent study it is indicated that "only a few studies have asked senior academic administrators about what they do, what they need to know, and what characteristics or attitudes they need to possess" (Townsend \& Bassoppo-Moyo, 1997:1; Mapp ,2008). Also while the educational policies and procedures play a significant role in the mission accomplishment of IHL, Deans are ultimately responsible for implementation of such policies and procedures. Some scholars such as Al-Shuaiby (2009), Fagin (1977) similarly contend that today the Dean is involved with the faculty and university, and the curriculum and in many ways are different from other institutional members.

Spendlove (2007) asserted, over the past ten years research in leadership effectiveness has moved towards identifying the leadership competencies such as knowledge, skills, abilities and behaviors of individuals. Also, Spendlove (2007) mentioned that, competencies are defined as sets of behaviors that are instrumental in the delivery of desired results or outcomes . (Bartram 2005). Even though some competencies are more difficult to learn than others (Tubbs and Schultz, 2005), however defining specific competencies can guide strategic human resource management practices in areas such as in recruitment and succession planning. Competencies and roles, offer a useful tool for leadership effectiveness. For effective leadership, competency models are not a prescription, but represent an attempt to capture the experience, lessons learned, and knowledge of seasoned leaders to provide a guiding framework for the benefit of others and the organization (Spendlove, 2007).

\subsection{The Tri-Dimensional Leadership Effectiveness Model}

Hersey and Blanchard's (1993) Tri-Dimensional Leadership Effectiveness Model explored the situational correlation between relationship behavior, task behavior and the readiness of the group. This model was based on the interaction between the leader and followers. This interaction is shaped by the maturity, ability and readiness level of followers mixed with the level of support provided by the leader (Hampton, Summer \& Webber, 1987). Hersey and Blanchard (1993) indicated that the situational leadership is based on an interplay among the following parts: (1) the amount of guidance and direction (task behavior) a leader gives; (2) the amount of socioeconomic support a leader provides; and (3) the readiness level that followers exhibit in performing a specific task, function or objective. Hersey, Blanchard, and Johnson (1996), in addition to other leadership theorists such as Fiedler (1967) and Blake and Mouton (1964), stressed that no single leadership style is appropriate for all situations. Effective leaders adjust their leadership behaviors to the readiness levels of subordinates. In the situational leadership model, the two dimensions of task and relationship are related to a third dimension, which are the maturity levels or readiness of the group or followers.

Readiness in the situational leadership is defined as the extent to which a subordinate demonstrates the ability and willingness to accomplish a specific assigned task. Readiness is not a personal attributes nor a person's traits, values, or age. Readiness is about how prepared a person may perform a particular task (Hersey, Blanchard, \& Johnson, 1996). Hersey, Blanchard and Johnson (1996) suggested four leadership styles that reflect behaviors along two dimensions. The first dimension, task behavior, consists of one-way communication and activities that are highly directive. In other words, the leader is explicit about assigning duties and responsibilities to be met by their subordinates. Leadership behaviors within this dimension include telling them what to do, how, when and where to do the assigned tasks. The second dimension is relationship behavior, focuses on the leader's facilitative ability to reach desired goals, and consists of two-way communication, providing support, encouragement and positive psychological feedback (Hersey, Blanchard, \& Johnson, 1996). Based on the Situational Leadership Model, leadership styles refer to four salient communication patterns the leader may use in talking to followers, which are telling, selling, participating and delegating. The two behaviors of telling and selling are primarily leader-oriented with one-way communications. Alternatively, participating and delegating are largely follower-oriented with two-way communication. Participating behaviors require the leader to invest considerable socio-emotional involvement in working with followers, while delegating behaviors involves and support. 


\subsection{The Vroom-Yetton Decision Making Model}

House relied heavily upon the expectancy theory developed by Vroom (1964) and others. Expectancy theory explains why people behave in certain ways in terms of an individual's goals and choices and the expectations of achieving objectives. Leaders have to create an environment in which workers understand and believe in the causal relationship between effort, performance, satisfaction and reward. Organizations have to set up environments of expectancies which support the motivation to perform (Hampton, Summer and Webber, 1987).

The Vroom-Yetton situational model enables leaders to effectively reach an informed determination on how to decide an issue. Baker (1996) stated that the model yields quality decisions and an indication whether a group will accept the decisions. The Vroom-Yetton model suggests three basic alternatives to the question of deciding who decides. Leaders using the autocratic method make unilateral decisions, using information he already possesses or information he has received from the group.

Consultative leaders obtain ideas and suggestions from individuals within the group, or from the group as a whole. In both instances, consultative leaders make decisions that may or may not reflect the contributions of the individual or group. Leaders advocating the group method are willing to accept the group's decision, and may or may not try to influence the decision. The Vroom-Yetton model hypothesizes that there are more than one acceptable solution to any problem. In those rare instances where there is only one solution, and that solution requires neither the support nor the acceptance of the group, either styles above could produce an acceptable answer (Baker, 1996). In majority of the cases, nevertheless, the decision-making process is much more complex, interdependent and dynamic.

The other integral element of the Vroom-Yetton approach is the question of time versus participation. Research demonstrates that while the autocratic style might produce quicker answers, the other approaches generally produce more qualitative answers. Then, the main components influencing the decision making process are: (1) Quality of the decision, (2) the acceptance by the group of the decision and (3) the time required to reach that decision (Vroom \& Yetton, 1973; Hampton et. al., 1987; Baker, 1996). A major weakness of the Vroom-Yetton model is that it fails to recognize differences among certain situations. Time constraints, amount of subordinate information and lack of physical proximity of the subordinates were also not considered in the original model. These shortcomings notwithstanding, Vroom and Jago's 1988 study (Yukl, 1998) found that the Vroom-Yetton model was successful approximately 62 percent of the time. Vroom and Jago modified and improved the original model, specifically addressing the information issue. The Vroom-Jago model incorporates significant improvements into the model.

\subsection{Leadership Effectiveness}

The Vroom-Yetton Model and the Tri-Dimensional Leadership Effectiveness Model represent contingency leadership theory. The basic, fundamental argument to contingency theory is that there is no one best way to lead. Contingency theory emphasizes for a leader to truly be effective, he or she must apply different leadership principles in different situations. The contingency model recommends that the effectiveness of a group depend upon the relationship between leadership style and the degree to which the group situation enables the leader to be influential. Fiedler (1967:9) said that "the effectiveness of a group or an organization depends on the interaction between the leader's personality and the situation". An effective leader finds more influence over followers by switching behavior, from task-oriented to relationship-oriented and back, based on the situation at hand. Contingency theory is presented to explain the impact of environmental factors and relationships with followers on leadership (Fiedler, 1967). Goleman, Boyatzie and McKee (2002) stated "The best, most effective leaders act according to one or more of six separate approaches to leadership and skillfully switch between the various styles depending on the situation".

\subsubsection{Leadership Effectiveness in Institutions of Higher Learning}

In this era of ever-expanding education, every group activity requires some sort of leadership to organize and direct the group's effort toward some previously decided goals. However, management and leadership are different from each other; they are remarkably close too, especially in the dimensions of human relationship. Leadership is the process whereby one individual affects the other members of the group towards the attainment of defined group or organizational goals. Success of different organizations, particular educational institutions depend on effective and efficient leaders. Al-Shuaiby (2009) indicated that numerous studies have also been conducted by a variety of researchers on a number of issues related to leadership effectiveness in IHL. In the process of evaluating any human performances, the most important issue is to identify a set of appropriate criteria. In order to identify the criteria for measuring leadership effectiveness of university presidents, McGoey (2005) conducted a survey of Deans, senior-level institutional officers, faculty Senate Chairpersons and student leaders. 
A study designed by Beck-Frazier (2005) attempted to investigate whether significant differences exist among the perceptions of leadership behaviors by Deans and Department Chairpersons. In IHL the middle managers are the academic Deans. The nature of the Deans' role and responsibilities is often viewed from different perspectives by faculty, Vice Chancellor, students and Deans themselves (Gmelch, Wolverton, \& Sarros, 1999). The effectiveness of Deans is often the result of informal assessments of their leadership style, the performance of their duties and individual traits or qualities (Rosser et al. 2000). A review of the literature identified a number of researchers have found significant relationships between leadership effectiveness and certain leadership styles (Corbin, 2000; Wheatley, 2001). After an extensive review of the literature, the researchers were interested in determining the extent to which leadership effectiveness of selected university Deans can be predicted by a combination of variables including their competencies, roles as well as leadership styles to be a significant factor in leadership effectiveness (Billing \& Alvesson, 1994; Daugherty \& Finch, 1997; Eagly et al., 1992; Eagly \& Johannesen-Schmidt, 2003; Moss \& Jensrud, 1995; Rosser et al., 2003; Thorp et al., 1998). The situational theory formulated by Hersey and Blanchard (2006) is utilized in this study in order to understand factors influencing leadership effectiveness of universities Deans. Based on their situational theory, Hersey and Blanchard (2006) have classified effectiveness of leaders into four different styles that could be drawn upon to deal with different situations: (a) Telling, which is considered as high task/low relationship behavior of the subjects; (b) Selling, which is considered as high task/high relationship behavior of the subjects; (c) Participating, which is considered as low task/high relationship behavior of the subjects; and (d) Delegating, which is considered as low task/low relationship behavior of the subjects.

\subsubsection{Hersey and Blanchard Leadership Styles}

Style 1 (Telling): This leadership style is distinguished by above-average amounts of task behavior and below-average amounts of relationship behavior. It is appropriate when a group is low in capacity and willingness and needs direction. Also it asserts directive behavior in which the leader identifies the roles of followers and tells them what, how, when and where to do various tasks (Hersey et al., 1996).

Style 2 (Selling): This style is differentiated by above-average amounts of both task and relationship behavior. The task behavior is suitable because people are still considered unable, but because they are trying, it is important to be supportive of their motivation and commitment. The leader sets up and maintains two-way communication and provides sufficient support and reinforcement so that followers will psychologically accept the leader's decisions (Hersey et al., 1996).

Style 3 (Participating): This leadership style is characterized by above-average amounts of relationship behavior and below-average amounts of task behavior. The decision-making procedure being shared by both the leader and follower demonstrate with this style. The leader maintains the role of confidence in the aptitude of his followers (Hersey et al., 1996).

Style 4 (Delegating): This style is described by below-average amounts of both relationship and task behavior. The followers are allowed to take charge and decide for themselves what, how, when and where to do various tasks. The leader shows complete confidence in his followers' aptitudes and decisions (Hersey et al., 1996).

More effective leaders establish which leadership style is most appropriate for them by first assessing the readiness level of the subordinates, which is their ability and willingness to perform the task. The two major factors of readiness are ability and willingness. The definition of the ability is the knowledge, experience, and skill that an individual or group brings to a particular task or activity. Willingness is the extent to which is an individual or group has the confidence, commitment, and motivation to accomplish a specific task (Hersey et al., 1996).

After recognizing the readiness level of the individual or group they are attempting to influence, the leader determines the most appropriate leadership style. Hence, styles adaptability is the extent to which the leaders are able to vary their style in response to the demands of a particular situation or problem. Hersey et al. (1996) suggested that all leaders have a primary leadership style and that most leaders have a secondary leadership style. A leader's primary leadership style is defined as the behavior pattern used most often when attempting to influence the activities of others, for example, a preferred follower. In leader's secondary leadership style the behavior pattern is the most often utilized only on occasion. Further, leaders have one primary leadership style, and they tend to use one of the four basic leadership styles described in Situational Leadership in most leadership situations. They may have no secondary leadership style or they may have up to three secondary styles.

\section{World Class Universities}

"World-class" universities are associated with the "top" universities in the various countries overseas, particularly in the United Kingdom (UK) and the United States. Besides, Suwanwela (2006) contends, Asia is a continent of diversity in many aspects, namely the physical, socio-economic and political status, the history of higher educational institutions, 
and the national policies and Asian countries are in different stages of national development. Whilst, higher education in Asian countries at present, is a new system brought into the region only in the last century. The structure and functions of universities are imported. It is believed that such principle has served mankind in the development and progress of human society and well-being. It is closely linked with government and administrative system in the countries, as well as with the structure and functions of the higher educational institutions. Recognition and understanding of these roles varies (Suwanwela, 2006). Moreover, higher education system in the region is facing new challenges, namely massification, limitation of resources, corporatization and privatization, globalization, information and communication technologies, as well as knowledge-driven economy and knowledge based society. Examining an organization's approach to leadership from the past to the future in Asian academic institutions, shows that a movement from more individual approaches (i.e., leadership as a position) to those that are more collective (i.e., leadership as a process) (Suwanwela, 2006).

Tierney (2007) believes that, there are at least five key trends and challenges that globalization has created for academic institutions. First, globalization means that a social activity such as education has no borders; students are able to take classes virtually anywhere in the world, in person or online. The second trend is to use relevant technology and see how it impacts the academic institution. A college or university is less of a physical place today and more an interaction that may well occurs not only on campus, but also may transpire on the Internet or any number of emergent virtual realities. Technology has been a central engine of globalization and it will continue to transform how we think about teaching, learning and research. Third, in a globalized world competition in the marketplace increases, students as customer have more choices about the kind of institutions they can attend and the kind of training they desire. Competition demands entities to think about how to compete or they will simply be obsolete. Fourth, globalization has weakened the social welfare role of the state and increased the importance of privatization. Fifty years ago a public college or university received most of its revenue from the state. Today, virtually all institutions have to raise a significant amount of resources from the private sector. The fifth challenge is that colleges and universities are more decentralized and decisions are made closer to where the action takes place. State planning or centralized decision making at the institutional level takes a backseat to entrepreneurial activity at the local level. In a competitive marketplace, departments and schools not only need a strategic plan, but they need to have clear criteria about how they judge unit performance. However, three themes demand analysis by any Department Chair or Dean that includes organizational mission, unit productivity, and individual performance.

\subsection{Model of Academic Excellence}

The term "global" is frequently used interchangeably with the terms "international", "multinational" and "transnational" although distinction has been made between these terms (Bartlett and Ghoshal, 1989; Adler and Bartholomew, 1992; Jokinen, 2004). Literally, the term "global "refers to something "pertaining to the whole world, world-wide, universal and comprehensive" (The Random House College Dictionary, 2005). Also, the definition of global leaders can be approached through the internationalization level of their responsibilities and activities.

Srinivas (1995) discussed eight definitions of "components of global mindset" which form the base for competencies needed to meet the challenges in organizations and individuals face when entering a global environment. These components include curiosity and concern with context, acceptance of complexity and its contradictions, diversity consciousness and sensitivity, seeking opportunity in surprises and uncertainties, faith in organizational processes, focus on continual improvement, extended time perspective and systems thinking. Rhinesmith (1996) identified six characteristics of global mindset that lead to global competencies. These are bigger, broader picture (leading to managing competitiveness), balancing contradictory demands and needs (managing complexity), trust in networked processes rather than in hierarchical structures (managing adaptability), valuing multicultural teamwork and diversity (managing teams), flow with change and seeing change as opportunity (managing uncertainty) and expanding knowledge and skills and being open to surprises (managing learning). For globalization, Jokinen (2004) suggested that leaders should have a global mindset, work as an equal with persons with diverse backgrounds, have a long-term orientation, facilitate organizational change, create learning systems, motivate employees to excellence, negotiate conflicts, lead and participate effectively in multicultural teams, direct skillfully the foreign employment cycle, understand their own values and assumptions, accurately profile the culture of others, and demonstrate knowledge and respect for other countries. Brake's (1997) model of "Global Leadership Triad" consists of four broader categories that are relationship management, personal effectiveness, business wisdom, and in the core, the transformational self. Gregersen et al.'s (1998) and Black et al. (1999) provided definitions about "a core set of global leadership characteristics" that consist of representing character, embracing duality and demonstrating ability with inquisitiveness as driving force. In the same line, Rosen (2000) maintained that globally literate leaders possess four "global literacy's". They include personal, social, business and cultural literacy. 


\section{Leadership Competency}

Competencies are defined as personal traits, behaviors, skills, values, knowledge and many other existing frameworks. After an extensive, the researchers agreed on the inclusion of four central leadership competencies or meta-competencies and their reviewes are included of cognitive ability, vision, interpersonal effectiveness and managerial effectiveness. Within these four meta-competencies, seventeen broad competencies are identified (Spendlove, 2007).

\subsection{Competencies and Academic Leadership Effectiveness}

Leaders in IHL should improve their leadership competencies to enable their universities and colleges to survive and continually develop. These competencies include leadership skills, communication skills, persuasive skills and professional skills. According to Yang (2005) the location of a university powerfully influences the university, positively or negatively. To be located in developed areas usually has a positive influence on a university. On the contrary, to be located in undeveloped areas has a negative impact on a university. There are four categories of leadership competencies identified by the faculties' members: Personality and disposition, personal knowledge and skill, administrative competency and social responsibility competency (Yang, 2005).

Gonzalez (2004) studied leadership competencies of Mexican senior administrators of IHL. She found that social forces and trends inside and outside of Mexican higher education institutions are driving the need for a senior administrator with a broad understanding of the national situation, with the resources to support the national initiative, and with the ability to make appropriate responses in their own institutions. Institutions of Higher Learning in these contexts play an important role in economic and social development (Yang, 2005). Also Gonzalez (2004) noted that the future senior administrators in these IHL must be equipped with: 1) Personal characteristics and skills, 2) administrative competencies, 3) competencies of social responsibility and 4) institutional competencies. Personal characteristics and skills include flexibility, anxiety control, time management, adaptive management, positive attitude toward people, innovative, motivating, honest, diplomatic, visionary and entrepreneurial spirit. Administrative competencies included decision-making, delegation, exploring alternatives, financial and administrative competencies, team work, communication, visioning, planning, negotiating, conflict resolution, evaluation, knowledge management, networking, marketing project management, and response capacity (Yang, 2005).

Competencies of social responsibility include social commitment, sensitivity to cultural diversity, analysis of demands, and knowledge of economic situation, and institutional competencies are contained institutional identity and philosophy, and leadership. Based on Yang (2005), leadership competencies identified by 22 Respondents in Chinese IHL are: (1) Devotion, (2) enthusiasm, (3) selflessness, (4) benevolence, (5) justice, (6) tolerance, (7) self-discipline, (8) kindness, (9) responsibility, (10) determination, (11) diligence, (12) commitment, (13) persistence, (14) flexibility, (15) charisma, (16) openness, (17) creativity, (18) initiative

Personal knowledge and Skill include: (1) A combination of Chinese and Western culture, (2) profound knowledge background, (3) knowledge about social reality, (4) knowledge of international higher education theory and practice, (5) international experiences and background, (6) higher academic reputation and achievement, (7) academic Discernment, (8) familiarity with the university (9) social skills (10) continuous learning ability, (11) English language skill, (12) critical thinking.

Administrative competency consists of: (1) Vision, (2) setting ambitious and achievable goals, (3) holistic mastery, (4) discernment, (5) collecting and processing information, (6) Strategic decision-making, (7) leading, (8) organizing, (9) coordinating, (10) evaluating and supervising, (11) motivating, (11) communicating, (13) staffing, (14) reconstructing new institutions,(15) resource-raising, (16) marketing.

Social responsibility competency include: (1) Political sensitivity and firmness, (2) implementing the national educational policy, (3) accomplishing university mission, (4) public figure, (5) service sense, (6) sense of opportunity, (7) sense of competition.

\section{Leadership Roles}

For many years there was strong interest in research related to leadership roles. Yukl (1998) concentrated on patterns of activities and roles specific to common to managers. Mintzberg (1973) and Baker (1998) expanded the behavior content for managers. Often differences in the research of managerial roles are intangible and are the result of semantics or of categorical groupings. Roles are defined as various behaviors a leader displays while functioning within an organization (Plunkett and Attner, 1989). As the leader engages with individuals within and outside the organization, his or her role requirements will be constantly shifting in accordance with the demands and desires of peers, subordinates and superiors. Mintzberg's book titled "Nature of Managerial Work" originally published in 1973 and revised in 1979, is one of the most important examinations of leadership roles. Much of the modern management theory today relies heavily upon 
Mintzberg's work. Mintzberg's (1979) view of leadership behavior complements various organizational behavior theories, and stressing the motivation of the individual, proper communication, leadership and decision making. Minztberg observed that managerial work encompasses ten roles, which is grouped into three major categories.

Interpersonal contact: In this category, the roles of figurehead, leader and liaison make up the interpersonal contact category. As a figurehead, the leader symbolizes and represents the organization by performing ceremonial duties. In the role of leader, he interacts with followers and also supports, motivates and develops followers. In the roles of a liaison, the leader establishes formal and informal networks to gain information critical to the success of the organization.

Information processing: It includes the roles of monitor, disseminator and spokesperson. In the monitor role, the leader gathers information both external and internal to the organization. As a disseminator, the leader distributes information to subordinates through formal and informal means. Acting as a spokesperson, the leader gives information to those outside the organization.

Decision making: It consists of the roles of entrepreneur, disturbance handler, resource allocator and negotiator. The entrepreneur designs and initiates organizational change and the disturbance handler handles problems arising from organizational conflict and disruption. As a resource allocator, the leader controls and schedules the allocation of personnel, time and financial resources. As a negotiator the leader represents the organization in both external and internal negotiations (Mintzberg, 1979:54-99).

\subsection{Roles and Academic Leadership Effectiveness}

Mintzberg (1973:188) stated that "the management school will significantly influence management practice when it becomes capable of teaching a specific set of "skills" associated with the job of managing". For example, students in different disciplines must learn various skills to be successful in their occupation (Sharples, 2002). Therefore, it is important for management students to learn leadership, negotiation, disturbance handling and other managerial skills (Mintzberg). Thus, it is important to identify different ways that academic leaders can develop the needed roles. According to Sharples (2002), the Leadership Competency Assessment Instrument (LCAI), written by Baker (1999) is a tool designed to measure leaders' competencies. Baker matched this tool from Mintzberg's (1973) managerial roles and is defined by behavior, particularly from the academic environments. In the following figure, conceptual framework of relationship between competencies, roles and Academic Leadership Effectiveness is shown (Figure 1).

$<$ Figure 1 about here $>$

\section{Human Resource Development (HRD) in the academic setting}

Human resource development (HRD) is a composite process in which knowledge accumulates through training, education as well as work and life experiences. It has been defined as an attempt to improve personal effectiveness through a planned and deliberate learning process (Mumford ,1987) and a conscious and systematic process to control the development of human resources in the organization for the achievement of goals and strategies (Molander ,1986). Development involves changing skills, knowledge, attitudes or behaviors. At the same time it should support the organization to achieve its strategic objectives and build a culture suitable for this direction (Tichy and Devanna 1986; Vicere 1997). Human Resource Development is an integral aspect of competencies building, development and regeneration, even though it does not cover all aspects of competence management. The traditional performance areas of HRD have been understood to involve: (1) Improving task performance, (2) enabling and supporting change implementation, (3) improving the quality of operations, (4) promoting creativity and innovation, (5) enhancing the employment prospects of individuals.

Then the organizations focusing on this approach seek competitive advantage primarily from capabilities and competencies. Any organization needs to engage in systematic HRD irrespective of how far learning culture has progressed in the organization. Development actions targeting employee competencies must be planned, implemented and assessed. In order to be efficient, development should be a systematic process instead of occasional. As a whole, HRD has so far focused very strongly on developing individuals.

Nevertheless, activities in organizations are more of a team function rather than the function of daring individuals (Leibman et al. 1996). Despite these benefits, the system has not been able to reach and impact all levels of the university system and personnel. The system assumed that the faculty and staff would have the requisite competencies for managing and leading quality within their environments. Any improvements desired in the operations of quality and that required training by academic units would be left up to them to do as needed. This means that Deans, heads of departments, professors, senior lecturers, program coordinators and others who have strategic roles in faculties through managing committees and courses would be required to interpret what competencies, roles would be needed to inform their operational quality and so engage in self-development. So this research will attempt to explore which particular 
competencies or roles are needed by the leaders in universities and utilizing these particular competencies or roles for developing academic leaders through specific training. The overall quality of a faculty or department would not be enhanced when only certain members assume that they are competent leaders and managers and have not been engaged in team building to improve their leadership and managerial capacity.

\section{Conclusion}

To conclude, effective academic leaders such the Deans and Head of Departments in research universities should use various leadership styles related to the situational model. Hersey and Blanchard proposed four leadership styles that include telling, selling, participating and delegating appropriate to the ability and willingness of followers to perform the assigned tasks. Also effective academic leaders require leadership competencies to perform the necessary leadership roles in a research university, especially when operating in a global context. A systematic leadership development program needs to be developed to ensure academic leadership effectiveness in research universities.

\section{References}

Al-Shuaiby ,A. (2009). Factors contributing to leadership effectiveness among Deans of Graduate Schools of Education .Dissertation Doctor of Education. The George Washington University.

Adler, N.J. and Bartholomew, S. (1992). Managing globally competent people. The Academy of Management Executive, $6(3), 52-65$.

Baker, G. A. III and Associates (1998). Organizational concepts and theories in the public sector. Raleigh, NC: North Carolina State University.

Baker, G.A. III \& Quinley, J. W. (July 1995). Power and influence in organizations: a review of the literature. In Baker, G.A. III (1996), EAC 600: Organizational concepts and theories: Macro-concepts in organizational behavior.

Unpublished course pack, North Carolina State University.

Bartlett, C.A. and Ghoshal, S. (1989). Managing across borders: The transnational solution, Boston, MA: Harvard Business School Press.

Black, J.S., Morrison, A.J. and Grgersen, H.B. (1999). Global explorers: The next generation of leaders, New York, Routledge,

Beck-Frazier, S.G. (2005). Perceptions of selected university deans' leadership behavior. An unpublished doctoral dissertation. East Carolina University.

Blake, R.R. \& Mouton, J.S. (1964). The managerial grid. Houston, TX: Gulf Publishing.

Billing, Y. D., \& Alvesson, M. (1994). Gender, managers, and organizations. New York: de Gruyter.

Blair, J. (2000). Schools of education tracking down big money. Education Week Number 22.

Brake, T. (1997). The Global Leader. Critical Factors for Creating The World Class Organization. Chicago, Irwin Professional Publishing, IL.

Corbin, C. (2000). Great Leaders See The Future First: Taking Your Organization To The Top In Five Revolutionary Steps. Chicago, IL: Dearborn Publishing.

Daugherty, L. H., \& Finch, C. R. (1997). Effective leadership of vocational administrators as a function of gender and leadership style. Journal of Vocational Education Research, 22(3).

Eagly, A. H., \& Johannesen-Schmidt, M.C., \& Engen, M.L. (2003). Transformational, transactional, and laissez-faire leadership styles: A meta-analysis comparing men and women. Psychological Bulletin, 129, PP. 569-591.

Eagly, A. H., Makhijani, M. G., \& Klonsky, B. G. (1992). Gender and the evaluation of leaders: A meta analysis. Psychological Bulletin, 108, 3-12. doi:10.1037/0033-2909.111.1.3, http://dx.doi.org/10.1037/0033-2909.111.1.3

Fagin, C. M. (1977). The leadership role of a dean. In M. J. Austin, F. L. Ahearn, \& R. A. English (Eds.), The professional dean: Meeting the leadership challenges.25( p. 95-99).

Fiedler, F. E. (1964). A contingency model of leadership effectiveness. In L. Berkowitz. Advances in experimental social psychology (Vol. 1, pp. 149-190). New York: Academic Press. doi:10.1016/S0065-2601(08)60051-9, http://dx.doi.org/10.1016/S0065-2601(08)60051-9

Fiedler, F. E. (1967). A theory of leadership effectiveness. New York: McGraw-Hill.

Jago, A. G. (1982). Leadership perspectives in theory and research. Management and Science, 28, 331-336. doi:10.1287/mnsc.28.3.315, http://dx.doi.org/10.1287/mnsc.28.3.315

Jonse.L.(2004). Academia and Industry Perspectives on Leadership and Human Resource Development Competencies Required for Agricultural Leadership Graduate Students Pursuing Industry Careers. University of Florida. 
Jokinen ,T.(2004).Global leadership competencies: a review and discussion Tiina Department of Management. University of Vaasa, Vaasa, Finland

Gregersen, H.B., Morrison, A.J. and Black, J.S. (1998). "Developing leaders for the global frontier", Sloan Management Review, Fall, pp. 21-32.

Goleman, D., Boyatzis, R., \& McKee, A. (2002). Primal leadership: Realizing the powerof emotional intelligence. Boston: Harvard Business School Press

Gmelch, W. H., Wolverton, M., Wolverton, M. L., \& Sarros, J. C. (1999). The academic dean: An imperiled species searching for balance. Research in Higher Education, 40, December, 717-740. doi:10.1023/A:1018717015528, http://dx.doi.org/10.1023/A:1018717015528

Gonzalez, M. G. Y. E. (2004). Perceptions of selected senior administrators of higher education institutions in Mexico regarding needed administrative competencies. Unpublished Doctoral Dissertation, Texas A\&M University, College Station.

Hampton, D.R., Summer, C.E., \& Webber, R.A. (1987). Organizational behavior and the practice of management (5th Ed.), Glenview, IL.: Harper-Collins.

Heck, R. H., Johnsrud, L. K., \& Rosser, V. J. (2000). Administrative effectiveness in higher education: Improving assessment procedures. Research in Higher Education, 41(6). doi:10.1023/A:1007096803784, http://dx.doi.org/10.1023/A:1007096803784

Hersey, P., \& Blanchard, K. H. (2006). Leader effectiveness and adaptability description (LEAD). Binghamton, NY: Center for Leadership Studies.

Hersey, P. \& Blanchard, R.H. (1993). Management of organizational behavior: Utilizing human resources (6th ed). Englewood Cliffs: N.J.-Hersey, P., \& Blanchard, K. H. (1969). Life cycle theory of leadership. Training and Development Journal, 23 (5), 26-34.

Hersey, P., Blanchard, K. and Johnson, D.E. (1996), Management of Organizational Behavior: Utilizing Human Resources, 7th ed., Prentice-Hall, Englewood Cliffs, NJ,

Leibman, M., Bruer, R. \& Maki, B.R. 1996. "Succession management: the next generation of succession planning". Human resource Planning. 19(3), 16-29

Mapp, W. (2008). Leadership Competencies and Their Development for Community College Administrators. Doctor of Philosophy.Applied Management and Decision Sciences. Walden University.

McGoey, S. P. (2005). A comparison of institutional stakeholders' perceptions of presidential effectiveness. An unpublished dissertation. Kent State University.

Mintzberg, H. (1973). The nature of managerial work. NY: Harper \& Row. Ming, K, Lee ,J and P,T . (2010) . Website of Education in Malaysia.

Mintzberg, H. (1979) .The nature of managerial work (2nd ed). New York: Harper \& Row.

Molander, C. (1986).Management Development, Bromley: Chartwell-Bratt. Parry, S.B. (1996), The Quest for Competencies". Training, July, 46-56.

Moss, J., \& Jensrud, Q. (1995). Gender, leadership, and vocational education. Journal of Industrial Teacher Education, 33(1).

Mumford, A. (1987). "Using reality in management development". Management Education and Development. 18(3), 223-243

Plunkett, W.R. \& Attner, R.F. (1989).Introduction to management. Boston: PWS-Kent Publishing Company.

Random House Webster's Unabridged Dictionary .(2005).Second Edition by Random House.

Rhinesmith, S.H.(1996). A Manager's Guide to Globalization: Six Skills for Success in a Changing World, 2 nd ed. The McGraw-Hill Companies, New York, NY.

Rosser, V. J., Johnsrud, L. K., \& Heck, R. H. (2003). Academic deans and directors:Assessing their effectiveness from individual and institutional perspectives.Journal of Higher Education, 74(1). doi:10.1353/jhe.2003.0007, http://dx.doi.org/10.1353/jhe.2003.0007

Sharples.R. (2002). The Importance of Leadership Competencies : Perceptions of North Carolina .Community College Presidents.

Spendlove .M. (2007). Competencies for effective leadership in higher education. International Journal of Educational Management. Aston University, Birmingham, UK. 21(5) pp 407- 417

Srinivas, K.M. (1995). "Globalization of business and the third world: challenge of expanding the mindsets", Journal of Management Development. 14 (3), pp. 26-49. doi:10.1108/02621719510078957,

http://dx.doi.org/10.1108/02621719510078957 
Suwanwela , C. (2006).Academic Freedom in Countries of Asia.

Teik.C.H .(2009). Enrolment in Tertiary Education Institutions. BY LEVELS OF STUDY (2000 - 2010).

Tierney .W. (2007).Department Chairs.Academic Leadership and Globalization. A RESOURCE FOR ACADEMIC ADMINISTRATORS .Spring 2007. 17(4).

Tichy, N. \& Devanna, N. (1986). The Transformational Leader. New York: John Wiley \& sons.

Thompson, J.E., Harrison, J. (2000). "Competent managers? The development and validation of a normative model using the MCI standards", Journal of Management Development, 19(9/10), pp.836-53.

doi:10.1108/02621710010357951, http://dx.doi.org/10.1108/02621710010357951

Thorp, L., Cummins, R., \& Townsend, C. (1998). Woman's self-perceived leadership skills in a collegiate agricultural education course. Journal of agricultural Education, 39 (1).

Townsend, B.K. \& Bassoppo-Moyo, S. (1997). The effective community college academic administrator: necessary competencies and attitudes. Community College Review, 25(2), 41-57. doi:10.1177/009155219702500204, http://dx.doi.org/10.1177/009155219702500204

Tubbs, S., Schultz, E. (2005). "Leadership competencies: can they be learned?", The Cambridge Business Review, 3 (2), pp.7-13.

Vicere, A.(1997). "How to design leadership development programs that gets results", 2nd Annual Leadership

Development Preconference Proceedings, Linkage Inc, San Francisco, CA.

Vroom, V.H., \& Yetton, P.W. (1973). Leadership and decision making. Pittsburgh: University of Pittsburgh Press.

Vroom, V.H., (1964). Work and motivation. New York: Wiley.

Wheatley, M. J. (2001, Spring). Innovation means relying on everyone's creativity.Leader to leader, 20, 14-20. New York, NY: The Drucker Foundation.

Wilking, K. A. (2004). Asian Pacific American female chief executive officers in higher education: Their challenges and strategies to the top. An unpublished doctoral dissertation).

Yang .X.(2005). Institutional Challenges and Leadership Competencies in Chinese Ministry of Education Directed Universities in Implementing the 1999 Chinese Action Scheme for Invigorating Education Towards the $21^{\text {ST }}$ Century. A Doctoral Dissertation Texas A\&M University

Yukl, G. (1998). Leadership in organizations (4th ed.). Upper Saddle River, NJ: Prentice Hall.

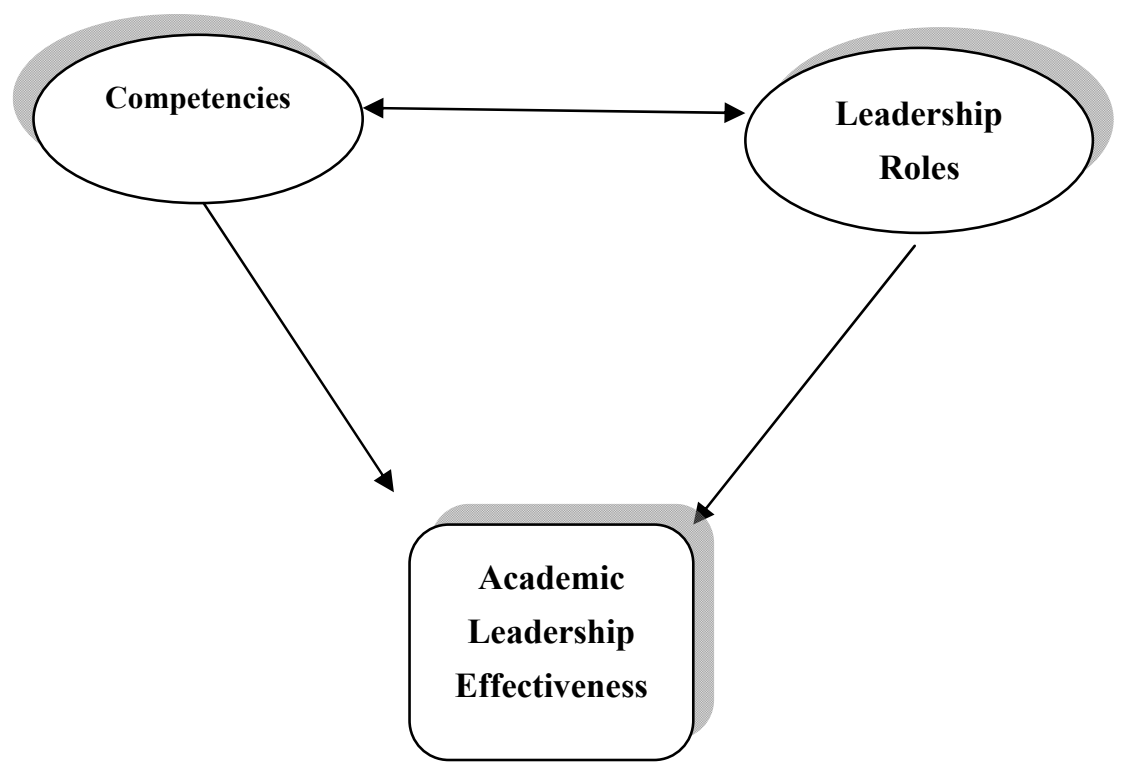

Figure 1. Competencies, Roles and Academic Leadership Effectiveness 